\title{
Comparison Between How To Learn Using The Book Media With The Internet Media Towards The Results Of Learning Learning In Industrial Chemistry In PIP Semarang
}

\author{
Darul Prayogo', Moh Zaenal Arifin², Mohammad Sapta Heriyawan ${ }^{3}$, Arya \\ Widiatmaja ${ }^{4}$ \\ \{darulprayogo@yahoo.co.id ,zaenalapip.smg@gmail.com²,hmsapta.kemenhub@gmail.com³,arya.pip.smg@gmail.com ${ }^{4}$ \} \\ 1,2,3,4Politeknik Ilmu Pelayaran (PIP) Semarang, Indonesia
}

\begin{abstract}
Learning is a process of changing one's personality where this change is in the form of improving quality, such as increasing knowledge, skills, thinking, understanding, attitudes, and various other abilities. Target of this research is first term cadet PIP Semarang. Researchers felt to do evaluation in teaching style following changing era dynamics. Question validity and reability determined by 0,367 and 0,60 . Test result shows that all question is valid and reliable. This research is quantitative research using corelasional survey method. Research shows that, cadet need internet to help them study in studying process. There's a difference between study achievement using press media and onlne in (PIP) Semarang, average study result using media is 51,25 meanwhile online media is 67,81 . There's a difference between study achievement using press media and online in PIP Semarang o need to be fixed in education field following the changing of era. Give permit using laptop with control from PMMK and use of private security. Use of modem and internet in group to increase study activities.
\end{abstract}

Keywords: Learn using the book, Internet Media, Study Result.

\section{Introduction}

Now we can access unlimited information on the internet. There is no more special material that can only be enjoyed by certain groups. Book is an information window. In this modern era, internet needed in education. Not only by reading book that can process and get information, internet can be larger than book as source of information. Information searching from internet is more faster and easy to do. Cadet has his way to get knowladge beside from teacher in campus.

Writer will point and compare study methode using online with book media. Is using internet media beside lesson book, cadet will be more good in achievement or the orther way arround? How cadet study result that everyday commonly use internet with cadet that commonly use book media?

\section{Literature Review}

Cadet got knowladge from the teacher in the class. they are pressed to use knowladge following changing era. Hariyanto (2011: 9) said that "Study is an activity or a process to 
getting knowladge, increase skill, fix manner, attitude and strengh then personality". Study result is abilities that student have after receiving study experience (Sudjana 2004: 22).

\section{Research Methodology}

This research, used quantitative research with corelasional method with searching connected to cadet way to study that use book with online media regarding to cadet result. This population research is all first term cadet PIP Semarang. Sample taking technique using Cluster Proportional Random Sampling.

\section{Analysis and Discussion}

\section{Descriptive Statistics}

\begin{tabular}{lr|r|r}
\multicolumn{2}{c|}{ Mean } & Std. Deviation & $\mathrm{N}$ \\
\hline VAR00001 & 51.25 & 17.244 & 48 \\
\hline VAR00002 & 67.81 & 12.920 & 48 \\
\hline
\end{tabular}

Average test score using press media is 51,25

Average test score using online media is 67,81

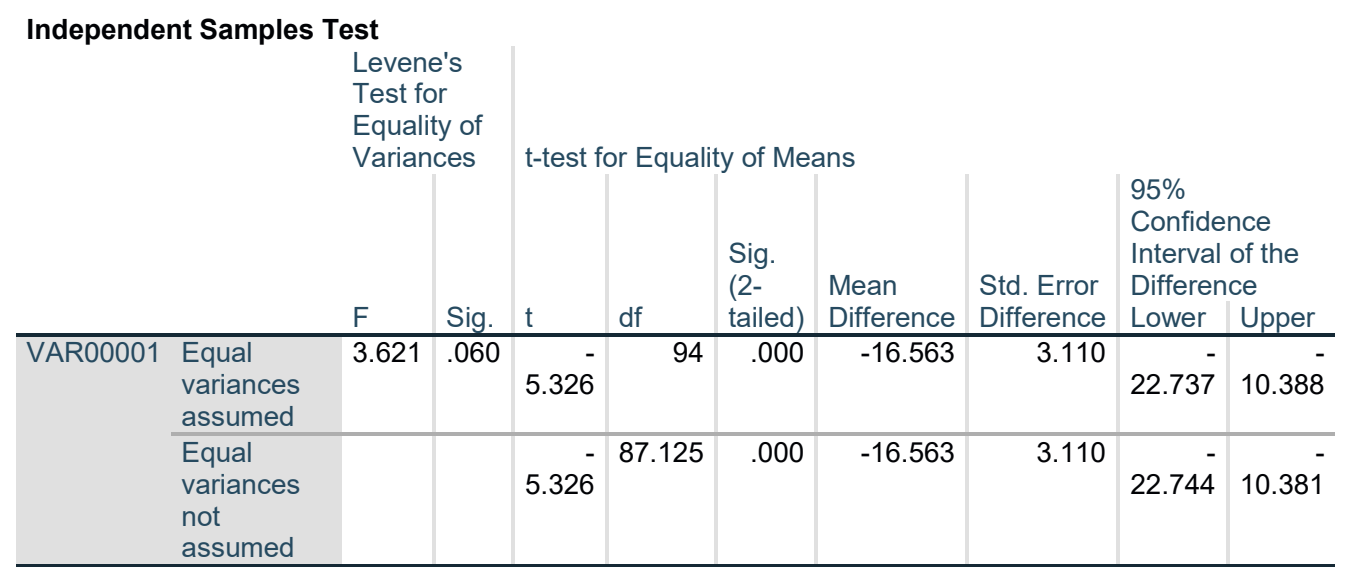

Output independent sample T-test above, got sig score. (2-tailed) $0,000<0,05$, so according to decusion takin in independent sample T-test, so can be concluded Ho got declined, Ha got accpected, than mean there's a difference in study achievement using press media and online.

Tscore counted negative mean average score using press media is lower than average score in online media.

Mean difference is $16,563(67,81-51,25)$ and difference between 10,388 until 22,737 (can be seen on lower and upper). 


\section{Closing}

A. Conclusion

1. Cadet need internet to help the learning process

2. There's a difference between study achievement using press media and online media in Politeknik Ilmu Pelayaran (PIP) Semarang, show with average study result using press media is 51,25 meanwhile average study result using online media is 67,81 .

\section{B. Suggestions}

1. Need fast used of internet for cadet to help studying process

2. There's a difference between study achievement using press media and online in PIP Semarang that need to be fixed in education field following the cahnging of era.

3. Give permit using laptop with control from PMMK and using private security.

4. Use of modem and internet in group to increase studying activity.

\section{REFERENCES}

Adji. R, Mesin Pendingin, 1977, Jakarta: persatuan Pelaut Insdonesia. Arismunandar. Wiranto, Penyegar Udara, 1980 Jakarta: PT. Pradya Paramita. Hamdani. Metodologi penelitian, 1994 Jakarta.

K. Handoko, Teknik Room Air Conditioner, 1996, Jakarta.

Kosasih. Engkos, Mesin Pendingin Dan Air Condition, Jakarta.

Prasetyo, Bambang,Lina Miftahul Jannah. 2010.Metode Penelitian Kualitatif. Jakarta: PT Rajagrafindo Persada.

Sudjana, Nana. 1989. Dasar-dasar Proses Belajar Mengajar. Bandung : Sinar Baru Algensido Offset.

http://pakjalpidie.blogspot.com/2013/01/pemanfaatan-internet-sebagai-media.html http://www.konsistensi.com/2013/01/teori-konsentrasi-belajar.html

http://abudaud2010.blogspot.com/2010/11/pengertian-dan-ciri-ciri-konsentrasi.html https://id.wikipedia.org/wiki/Buku https://www.academia.edu/4908893/Perbandingan_Antara_Cara_Belajar_Menggunakan_Med ia_Buku_dengan_Media_Internet_Terhadap_Tingkat_Konsentrasi_Belajar_Siswa http://www.spssindonesia.com/2016/08/cara-uji-paired-sample-t-test-dan.html http://www.spssindonesia.com/2015/05/cara-uji-independent-sample-t-test-dan.html http://www.statistikolahdata.com/2010/10/analisis-perbandingan.html https://teorionline.wordpress.com/2011/02/24/paired-sample-t-test-uji-beda-dua-sampelberpasangan/

1 Diakses melalui : http://pakjalpidie.blogspot.com/2013/01/pemanfaatan-internet-sebagaimedia.html pada 18 Juni 2013 pukul 13.00 WIB

${ }^{1}$ Diakses melalui : http://www.konsistensi.com/2013/01/teori-konsentrasi-belajar.html Pada tanggal 18 Juni 2013 pukul 14.00 WIB ${ }^{1}$ Loc cit.,

${ }^{1}$ Diakses melalui : http://abudaud2010.blogspot.com/2010/11/pengertian-dan-ciri-cirikonsentrasi.html pada tanggal 18 Juni 2013 pukul 14.15 WIB

${ }^{1}$ Diakses melalui https://id.wikipedia.org/wiki/Buku pada 19 Juni 2013 pukul 20.05 WIB 
http://sumberdaya.ristekdikti.go.id/index.php/2018/01/30/era-revolusi-industri-4-0-saatnyagenerasi-millennial-menjadi-dosen-masa-depan/ 